\title{
Review
}

\section{Agonistic democracy: Constituent power in the era of globalisation}

\author{
Mark Wenman \\ Cambridge University Press, New York, 2013, xvii+334pp., $£ 65.00$ / \$99.00, \\ ISBN: 978-1107003729 \\ Contemporary Political Theory (2015) 14, e8-e11. doi:10.1057/cpt.2014.2; \\ published online 28 October 2014
}

In Agonistic Democracy, Mark Wenman sets out to provide a systematic account of agonistic democracy in order to disprove what he perceives as a common prejudice, namely, that 'the agonistic perspective is less coherent and well developed' (p. 3) than other conceptions of democracy. According to Wenman, the theoretical basis of agonism consists of the ideas of pluralism, tragedy and the value of conflict, while democracy is to be understood as a founding moment (rather than a form of government) and finds its expression in the notion of constituent power. Constituent power, Wenman suggests, may emerge in two different modes. While augmentation describes 'a (re)foundation that simultaneously expands and preserves an existing system of authority', a revolution 'is characterised by an absolute beginning ... that brings a new principle or set of norms and values into the world, as it were ex nihilo' (p. 9). Wenman assumes that a consistent theory of agonistic democracy needs to consider both modes of constituent power as essential manifestations of democracy.

Against this theoretical background, Wenman discusses the works of four theorists whom he depicts as leading figures in the field of agonistic democracy: William Connolly, James Tully, Chantal Mouffe and Bonnie Honig. The main thesis put forward is that these authors one-sidedly focus on constituent power as augmentation and theoretically foreclose the possibility of revolutionary change. Although they all advocate the possibility of genuine political innovation, they envisage change merely as something 'extra-in-the-ordinary' (p. 251), in the sense that they principally acknowledge the legitimacy of liberal democratic institutions and practices. Wenman considers this a serious problem because he assumes that the current global state of affairs, for whose description he primarily draws on Hardt and Negri's theory of empire, calls for radical change that would introduce new social and political forms. In light of this, he concludes the book with the outline of a model of 'militant cosmopolitanism' that is meant to improve on the prevailing theories of agonistic 
democracy by taking 'a more militant stance towards existing institutions and practices' (p. 264).

In my view, two aspects of the book deserve special attention. The first is the idea of two modes of constituent power. The remarkable distinction between revolution and augmentation, which Wenman extracts from Hannah Arendt's writings, carries considerable potential for theoretical innovation, even beyond the context of agonistic democracy. In particular, it might enrich democratic and constitutional theory's research on legitimate modes of constitutional politics. With the differentiation between an extraordinary and an extra-in-the-ordinary mode of constituent power, Wenman joins the choir of those who strive to overcome the rigid distinction between pouvoir constituant as a pre-constitutional political capacity that only emerges in revolutionary constitutional moments and is subsequently absorbed by the constitutional system, and, on the other hand, the power of constitutional reform that is exercised by constituted entities through legally codified procedures (for middle positions see Ackerman, 1991; Colón-Ríos, 2012). The concept of augmentation describes a mode of constitutional politics that lies in between revolution and reform as it does neither aim at the replacement of the constitutional order nor proceed in accordance with the pre-defined legal procedures for piecemeal constitutional change. To explain what specifically distinguishes revolution and augmentation, Wenman draws on the categories of alegality and illegality. While constituent power in the revolutionary mode is alegal because it precedes the new constitutional order it aims to create, constituent power as augmentation is an illegal act 'that ruptures a given framework of norms, but nonetheless emerges from and remains explicable within its broader horizon of meaning and legitimacy' (p. 163).

To put it differently, while revolutionary constituent power stands in an absolutely external and adverse relation to the established constitutional framework, pouvoir constituant in the mode of augmentation is committed to the current order's basic principles that it strives to realize in new forms. While the idea of two different modes of constituent power is not entirely new (see Kalyvas, 2008, pp. 297-300), we still lack a comprehensive account of the conditions under which non-revolutionary forms of constitutional politics involving legal breaks may claim democratic legitimacy. In this regard, future research might break new ground by developing an output-oriented differentiation between progressive and regressive augmentations. Augmentations that improve the realization of a given democratic order's basic principles (for example, by giving the right to vote to formerly disenfranchised groups) could be described as progressive and therefore be assessed as potentially democratically legitimate, whereas processes of augmentation that undermine these principles could be evaluated as regressive and hence illegitimate. It is important to note, however, that while Wenman's considerations on constituent power provide inspiration and valuable starting points for research in this direction, he himself would reject normative questions of democratic legitimacy and especially the notion 
of a progressive development as strongly misguided - which leads to my second point of discussion: the question of normativity.

According to Wenman, agonistic democracy must 'refuse all normativity' (p. 280). This claim is rooted in two of the aforementioned basic components of agonism: first, in the concept of 'constitutive pluralism' that describes modern societies as communities featuring an ineradicable pluralism of conflicting values for whose ordering we lack an objective standard and, second, in the 'tragic view of the world' according to which conflict, suffering and strife are inevitable phenomena of social and political life and may never be ultimately overcome. From this perspective, it seems that theoretical attempts to formulate normative requirements for legitimate political action represent unjustifiable impositions with exclusionary effects. Accordingly, Wenman tracks down and criticizes any trace of normativity in the accounts of agonistic democracy he discusses. For example, Tully's concept of agonistic dialog, which demands reciprocity and mutual respect from the participants of political processes, is said to represent 'a dangerous digression from the properly tragic viewpoint of agonism' (pp. 138-139).

Although Wenman is keen to emphasize that agonism is a non-normative 'strategic and tactical doctrine' (p. 39), it seems that his own account of agonistic democracy cannot avoid drawing on certain minimal normative standards either. Of course, even the 'politics of militant conviction' (p. 265) he advocates is not supposed to proceed violently. While Wenman refuses to explicate normative requirements for legitimate agonistic politics, he clearly affirms 'a constructive mode of contest and rivalry' (p. 46) and rejects forms of hostility. But how could we tell acceptable and unacceptable forms of conflict apart without a normative standard of some kind? What distinguishes the 'democratic actor' (p. 286) from, say, the fundamentalist, if not the normative quality of her political actions? The need for a corresponding standard shines through, for example, when Wenman suggests that agonistic political action should be guided by 'the public virtues associated with the art of persuasion' (p. 287). In light of this, however, the critique directed against Tully, among others, seems overstated. In general, doubts remain whether a convincing theory of agonistic democracy can really abstain from any normative elements making a claim to context-transcending validity.

All in all, Agonistic Democracy is a provocative as well as thought-provoking book that is certainly of interest to scholars working in the field of agonistic democracy as well as to legal and political theorists from non-agonistic theoretical backgrounds engaging in the recently intensifying debate on constituent power.

\section{References}

Ackerman, B. (1991) We the People: Foundations. Cambridge, MA: Harvard University Press. 
Colón-Ríos, J. (2012) Weak Constitutionalism: Democratic Legitimacy and the Question of Constituent Power. London and New York: Routledge.

Kalyvas, A. (2008) Democracy and the Politics of the Extraordinary: Max Weber, Carl Schmitt, and Hannah Arendt. New York: Cambridge University Press.

Markus Patberg

University of Hamburg, 20148 Hamburg, Germany 